\title{
Availability to pigs of amino acids in cereal grains
}

\section{Endogenous levels of amino acids in ileal digesta and faeces of pigs given cereal diets}

\author{
BY M. R. TAVERNER*, I. D. HUME AND D. J. FARRELL \\ Department of Biochemistry and Nutrition, University of New England, Armidale, \\ NSW 2351, Australia
}

(Receivea' 4 September 1979 - Accepted 4 February 1981)

\begin{abstract}
1. Endogenous levels of amino acids in ileal digesta were determined as the output from pigs given protein-free diets and by extrapolation to zero intake of linear regressions of ileal amino acid output $v$. dietary amino acid intake. The protein-free diets included 0 or $50 \mathrm{~g}$ cellulose $/ \mathrm{kg}$ and extrapolations were made from two series of four diets which contained graded levels of wheat or barley as the only source of protein. Within each series, dietary fibre level $(\mathrm{mg} / \mathrm{g})$ was maintained at approximately 140 or 190 neutral-detergent fibre (NDF) respectively. Endogenous amino acid levels in faeces were also determined.

2. Endogenous amino acid output in faeces was linearly related to dietary fibre level; endogenous ileal output increased with dietary fibre up to approximately $100 \mathrm{mg} \mathrm{NDF} / \mathrm{g}$, after which endogenous output no longer increased.

3. The amino acid composition of endogenous ileal protein varied little among levels of output and among different experiments. The composition appears to be determined by the predominance of mucin protein, the slow absorption of some amino acids c.nd the methods commonly used to measure output. The very high levels of proline and glycine in ileal digesta seemed characteristic only of protein-free and low-protein diets.

4. The amino acid composition of endogenous faecal protein also varied little among different estimates, but was considerably different from that of endogenous ileal protein. Furthermore, the similarity of bacterial and faecal proteins suggested that much of the endogenous faecal protein was of bacterial origin.
\end{abstract}

In cereal protein, as in most other plant protein, amino acids are not wholly available for utilization by the animal because of incomplete digestion and absorption (Miller, 1976). Therefore, as a measure of disappearance of dietary amino acids from the stomach and small intestine of the pig, ileal c.nalysis should provide a meaningful estimate of the biological availability of amino acids in cereal grains. In practice however, there are problems both with the collection of unabsorbed material from the ileum (Laplace \& Borgida, 1976) and with the apportioning of the amino acids in ileal digesta to dietary or endogenous sources. Simplifed (Ivan, 1974; Zelorowska et al. 1978) and automated (Borgida \& Laplace, 1977) collection techniques have been developed to ease difficulties with ileal collections, but there have been few studies of the levels of endogenous amino acids in ileal digesta. In his review, Low (1976) concluded that much more information is required before correction of nutrient digestibility values for spezific endogenous secretions can be made with confidence.

The major aim of the present study was to determine values of endogenous ileal and faecal amino acid output appropriate for the calculation of true amino acid digestibility in cereal diets. In this study two methods were used to determine levels of endogenous amino acids in digesta collected at the terminal ileum and in faeces. First, endogenous values were measured in the output from pigs given protein-free diets. Second, linear regressions of amino acid output on dietary intake were determined with pigs given each of two series of four diets in which gradied levels of either wheat or barley were the only protein sources and endogenous values were measured from these regressions by calculating output values

- Present address: Animal Research Institute, Werribee, Victoria, 3030, Australia. 
at zero intake. The experiment also provided both a comparison between endogenous amino acid values determined at different levels of dietary fibre and a comparison between endogenous faecal and ileal amino acid levels.

\section{EXPERIMENTAL PROCEDURES}

\section{Animals and their management}

Five male pigs, each with a re-entrant ileal cannula (Ash, 1962), were used at a mean live weight of $86( \pm 3.5) \mathrm{kg}$. The average live weights during the period each series of diets was offered is shown in Table 1. The animals were maintained in Shinfield metabolism crates (Frape et al. 1968) incorporating a side door to allow access to the cannula. The temperature of the room in which the pigs were housed was approximately $21^{\circ}$. The pigs were offered $0.8 \mathrm{~kg}$ air-dry diet mixed with approximately 21 water at $12 \mathrm{~h}$ intervals.

Each diet was offered for $12 \mathrm{~d}$ and ileal digesta were collected for three $12 \mathrm{~h}$ periods from each pig on the third, fifth and twelfth days, and faeces were totally collected from the ninth to the eleventh day. During ileal collections a plastic bag was attached to the proximal cannula and a soft plastic return tube attached to the distal cannula. Digesta generally appeared in the bag as discrete expulsions of approximately $50 \mathrm{~g}$, following which the sampling bag was replaced, the sample weighed and placed in ice. A similar quantity of digesta collected previously and warmed to $37^{\circ}$ was then returned to the pig through the distal cannula. After each $3 \mathrm{~h}$ period during the collection the separate samples of digesta were combined and a portion of $10 \mathrm{mg} / \mathrm{g}$ total weight was taken and stored in sealed containers at $-20^{\circ}$ for analysis.

\section{Diets}

The compositions of the diets are presented in Table 2. Chromic oxide was added to each diet for the estimation of ileal and faecal digestibility values. Starch and pure wood cellulose (Solkafloc) replaced cereal grain so that within each diet series the contents of digestible energy and neutral-detergent fibre (NDF) were maintained almost constant.

The grain included in these diets was ground to pass through a $1.58 \mathrm{~mm}$ sieve.

\section{Analytical methods}

Faeces and digesta samples were freeze-dried to constant weight and then ground through a $1 \mathrm{~mm}$ sieve. The four samples of digesta from each $12 \mathrm{~h}$ period were then combined for analysis. Nitrogen was determined by Kjeldahl digestion using sulphuric acid and selenium catalyst followed by the autoanalyser method of Clare \& Stevenson (1964). Chromium content was determined by atomic absorption using an acetylene-nitrous oxide flame. Dietary NDF content was determined by a method based on that described by Van Soest \& Wine (1967) but in which the sample was incubated with amylase before detergent treatment and the fibre residue was recovered by centrifugation rather than filtration (Angus et al. 1977). Amino acids were determined by ion-exchange chromatography (Spackman

Table 1. The average liveweights $(\mathrm{kg})$ of pigs during the period each series of diets was offered

\begin{tabular}{lrrrrrr}
\hline & \multicolumn{6}{c}{ Pig } \\
\cline { 3 - 7 } Diet $^{*}$ & A & B & C & D & E \\
\hline Wheat series & 99 & - & 89 & 62 & 66 \\
Barley series & 113 & 81 & - & - & 83 \\
Protein-free & 88 & 108 & 107 & - & 55 \\
\hline \hline
\end{tabular}

* For details, see Table 2. 
Table 2. Composition $(\mathrm{g} / \mathrm{kg})$ of experimental diets

\begin{tabular}{|c|c|c|c|c|c|c|c|c|c|c|}
\hline \multirow[b]{2}{*}{ Ingredients ${ }^{*}$} & \multicolumn{4}{|c|}{ Wheat series } & \multicolumn{4}{|c|}{ Barley series } & \multicolumn{2}{|c|}{ Protein-free } \\
\hline & Wl & W2 & w3 & W4 & B1 & B2 & B3 & B4 & PFO & PF5 \\
\hline Wheat & $971 \cdot 7$ & $700 \cdot 0$ & $450 \cdot 0$ & $250 \cdot 0$ & - & - & - & - & - & - \\
\hline Barley & - & - & - & - & $971 \cdot 7$ & $750 \cdot 0$ & $500 \cdot 0$ & $250-0$ & - & - \\
\hline Starch & - & 232.9 & $451 \cdot 5$ & $624 \cdot 6$ & - & $175 \cdot 5$ & 379.9 & $583 \cdot 2$ & $971 \cdot 1$ & 871.7 \\
\hline Solka-floc & -. & 38.8 & $70 \cdot 2$ & $97 \cdot 1$ & - & $46 \cdot 2$ & $92 \cdot 3$ & $138 \cdot 5$ & - & 50.0 \\
\hline Oil† & - & - & - & - & - & - & - & - & - & $50 \cdot 0$ \\
\hline Bone meal & $20 \cdot 0$ & $20 \cdot 0$ & 20.0 & $20 \cdot 0$ & $20 \cdot 0$ & $20 \cdot 0$ & 20.0 & $20 \cdot 0$ & $20 \cdot 0$ & $20 \cdot 0$ \\
\hline \multicolumn{11}{|c|}{ Chemical analysis +} \\
\hline Nitrogen & 21.6 & 16.8 & $11 \cdot 3$ & $6 \cdot 1$ & 21.7 & $16 \cdot 4$ & $11 \cdot 5$ & 5.7 & 1.4 & 1.5 \\
\hline Neutral detergent fibre & 130 & 142 & 143 & 139 & 186 & 192 & 192 & 197 & 0 & 49 \\
\hline
\end{tabular}

- To each $\mathrm{kg}$ of diet $8.3 \mathrm{~g}$ micronutrients was included. These microingredients included ( $\mathrm{g} / \mathrm{kg}$ diet): 5 sodium chloride, 2 chromic oxide and 1.3 vitamin and mineral premix described by Ivan (1974).

$\dagger$ Blended animal fats.

$\ddagger$ Dry matter basis.

Table 3. Average values for dry matter (DM) of food intake, ileal and faecal digestibility, the disappearance of DM and nitrogen from the large intestine and the DM content of ileal digesta of pigs given diets in the wheat or barley diet series*

\begin{tabular}{|c|c|c|c|c|c|c|}
\hline \multirow[b]{2}{*}{ Diet } & \multirow{2}{*}{$\begin{array}{c}\text { DM } \\
\text { intake } \\
(\mathrm{g} / 12 \mathrm{~h})\end{array}$} & \multicolumn{2}{|c|}{$\begin{array}{c}\text { DM } \\
\text { digestibility }\end{array}$} & \multicolumn{2}{|c|}{$\begin{array}{l}\text { Disappearance from } \\
\text { large intestine } \\
\text { (g/kg DM intake) }\end{array}$} & \multirow{2}{*}{$\begin{array}{l}\text { DM content o } \\
\text { ileal digesta } \\
(\mathrm{g} / \mathrm{kg})\end{array}$} \\
\hline & & Ileum & Faeces & DM & $\mathbf{N}$ & \\
\hline \multicolumn{7}{|c|}{ Wheat series } \\
\hline Wl & 680 & $0.78^{a}$ & $0.85^{a}$ & $75^{a}$ & $1 \cdot 2^{a}$ & $94^{a}$ \\
\hline W2 & 696 & $0.78^{a}$ & $0.87^{a}$ & $91^{a}$ & $0.7^{a}$ & $100^{a}$ \\
\hline W3 & 687 & $0.79^{a}$ & $0.89^{b}$ & $95^{a}$ & $0.8^{a}$ & $99^{a}$ \\
\hline W4 & 677 & $0.79^{a}$ & $0.90^{b}$ & $113^{a}$ & $0.8^{a}$ & $105^{a}$ \\
\hline SEM & & 0.005 & 0.008 & $12 \cdot 6$ & 0.64 & $4 \cdot 3$ \\
\hline \multicolumn{7}{|c|}{ Barley series } \\
\hline B1 & 704 & $0.73^{a}$ & $0.82^{a}$ & $89^{a}$ & $1 \cdot 8^{a}$ & $102^{a}$ \\
\hline B2 & 704 & $0.73^{a}$ & $0.83^{a b}$ & $96^{a}$ & $1 \cdot 5^{a b}$ & $106^{a}$ \\
\hline B3 & 708 & $0-76^{b}$ & $0.86^{c}$ & $97^{a}$ & $1 \cdot 3^{b}$ & $103^{a}$ \\
\hline B4 & 700 & $0.74^{a}$ & $0.85^{b c}$ & $109^{a}$ & $1 \cdot 1^{b}$ & $99^{a}$ \\
\hline SEM & & 0.006 & 0.006 & 8.0 & 0.14 & 1.7 \\
\hline
\end{tabular}

$a, b, c$, Within columns and within diet series, means followed by different superscripts differed significantly $(P<0.05)$.

- For details, see Table 2.

et al. 1958) following proten hydrolysis in $6 \mathrm{M}$-hydrochloric acid in sealed, evacuated tubes maintained at $110^{\circ}$ for $21 \mathrm{~h}$. Amino acid concentrations were calculated relative to a standard $25 \mathrm{~nm}$ mixture of amino acids. Nor-leucine was used as an internal standard. Because of a generally poor resolution between the peaks on the chromatogram for histidine and ammonia, and the poor duplication ( $>5 \%$ ) for tyrosine and phenylalanine, results of these amino acids have been excluded. Tryptophan and cystine contents were not determined and caution may be required in interpreting methionine data due to its possible underestimation because of oxidation during hydrolysis. 


\section{Statistical methods}

The relationships between amino acid output and input were analysed by regression analysis. A $t$ test was used to test for significant differences between two estimates of endogenous output except when variances were significantly heterogenous when the method of Sukhatmé (1938) was used.

\section{RESULTS}

The contents of $\mathbf{N}$ and NDF of the experimental diets are presented in Table 2.

Average values for dry matter (DM) of food intake, ileal and faecal digestibilities and of disappearance of $\mathbf{N}$ from the large intestine, are shown in Table 3. Apart from pigs given diet B3, the average digestibility of DM at the ileum did not vary within each diet series. However, faecal DM digestibility increased $(P<0.05)$ as starch and cellulose replaced grain in the diet.

\section{Endogenous ileal output}

Extrapolated values. Generally, the regression coefficients of the linear regression equations of ileal amino acid flow (mg/ $\mathrm{kg}$ DM intake) $v$. dietary amino acid intake were positive and statistically significant. However, ileal levels of glycine were poorly related to glycine intake and for most pigs the regression coefficients were not significant; similarly, with proline

Table 4. Endogenous ileal output of amino acids and nitrogen ( $\mathrm{mg} / \mathrm{kg}$ dry matter intake) in pigs given diets in the wheat or barley diet series*

(Mean values with their standard errors. No. of pigs in parentheses)

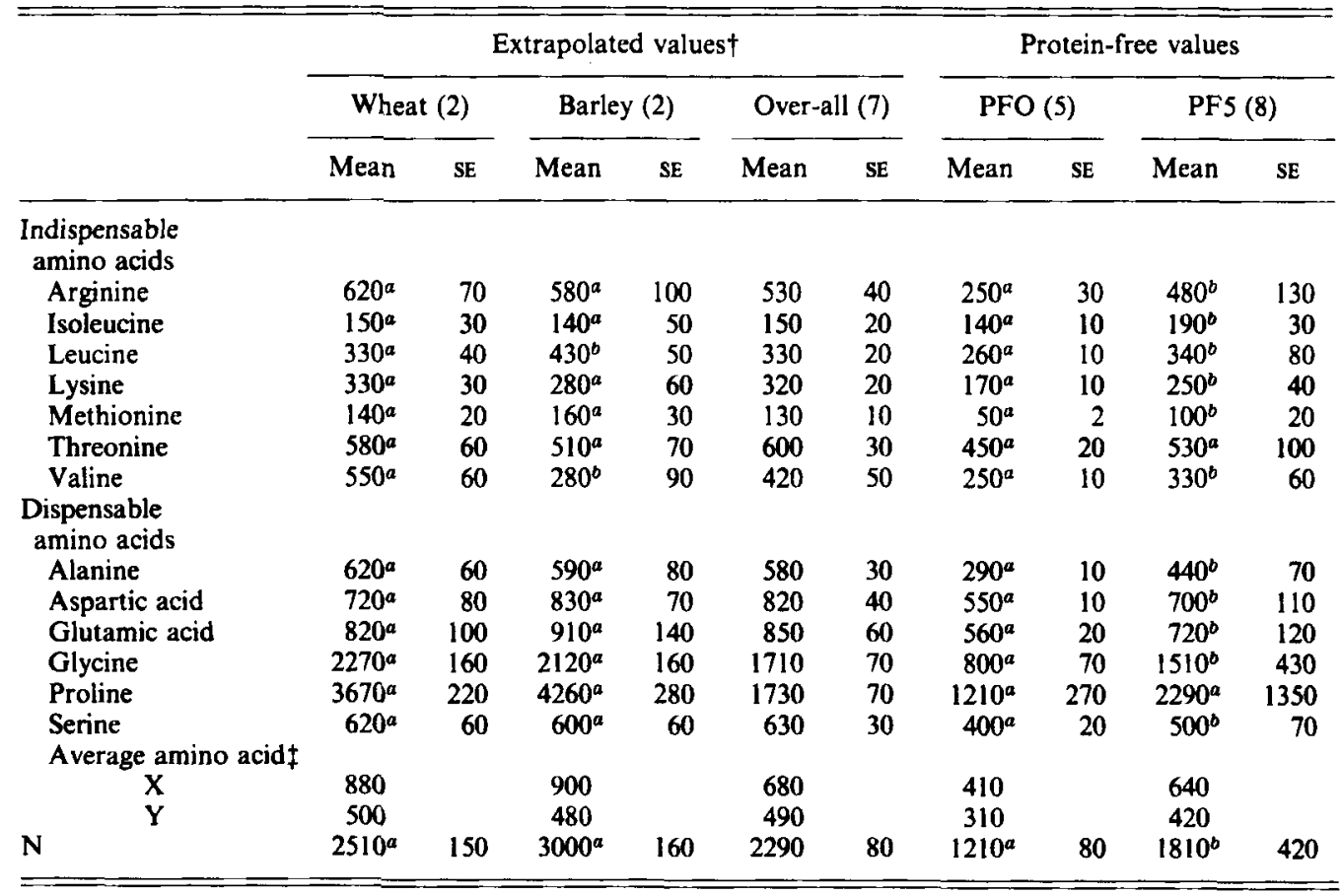

$a, b$, Within rows and within each method, means followed by different superscripts differed significantly $(P<0.05)$.

* For details, see Table 2.

$\dagger$ Values determined by extrapolation to zero intake of linear regressions of ileal amino acid output $v$. dietary amino acid intake.

$\ddagger$ Average $\mathrm{X}$ includes all amino acids listed, $\mathrm{Y}$ excludes values of glycine and proline. 
Table 5. Endogenous faecal output of amino acids and nitrogen ( $\mathrm{mg} / \mathrm{kg}$ dry matter intake) in pigs given diets in the wheat or barley diet series*

(Mean values with their standard errors. No. of pigs in parentheses)

\begin{tabular}{|c|c|c|c|c|c|c|c|c|c|c|}
\hline & \multicolumn{8}{|c|}{ Extrapolated values } & \multirow{2}{*}{\multicolumn{2}{|c|}{$\frac{\text { Protein-free }}{\text { PF5 (3) }}$}} \\
\hline & \multicolumn{2}{|c|}{ Wheat (2) } & \multicolumn{2}{|c|}{ Barley (2) } & \multicolumn{2}{|c|}{ Wheat (4) } & \multicolumn{2}{|c|}{ Barley (3) } & & \\
\hline & Mean & SE- & Mean & SE & Mean & $\mathbf{S E}$ & Mean & SE & Mean & SE \\
\hline \multicolumn{11}{|l|}{$\begin{array}{l}\text { Indispensable } \\
\text { amino acids }\end{array}$} \\
\hline Arginine & $190^{\alpha}$ & 90 & $210^{a}$ & 80 & 200 & 60 & 320 & 80 & 130 & 10 \\
\hline Isoleucine & $330^{\alpha}$ & 60 & $460^{b}$ & 50 & 350 & 50 & 460 & 70 & 160 & 20 \\
\hline Leucine & $430^{a}$ & 80 & $700^{b}$ & 80 & 470 & 80 & 670 & 70 & 250 & 30 \\
\hline Lysine & $390^{a}$ & 110 & $620^{b}$ & 50 & 400 & 80 & 590 & 70 & 200 & 20 \\
\hline Methionine & $250^{a}$ & 50 & $280^{a}$ & 70 & 230 & 30 & 280 & 30 & 70 & 10 \\
\hline Threonine & $360^{a}$ & 60 & $480^{b}$ & 60 & 410 & 60 & 490 & 60 & 200 & 20 \\
\hline Valine & $400^{a}$ & 80 & $610^{b}$ & 120 & 420 & 80 & 620 & 80 & 180 & 20 \\
\hline \multicolumn{11}{|l|}{$\begin{array}{l}\text { Dispensable } \\
\text { amino acids }\end{array}$} \\
\hline Alanine & $410^{a}$ & 80 & $710^{\circ}$ & 90 & 480 & 70 & 580 & 90 & 230 & 20 \\
\hline Aspartic acid & $730^{a}$ & 120 & $1030^{b}$ & 120 & 780 & 90 & 1030 & 110 & 350 & 40 \\
\hline Glutamic acid & $750^{a}$ & 140 & $930^{a}$ & 250 & 800 & 130 & 990 & 170 & 390 & 40 \\
\hline Glycine & $320^{\circ}$ & 80 & $570^{b}$ & 50 & 390 & 70 & 510 & 110 & 180 & 20 \\
\hline Proline & $330^{a}$ & 120 & $510^{\alpha}$ & 130 & 340 & 80 & 500 & 110 & 130 & 20 \\
\hline Serine & $310^{\alpha}$ & 70 & $450^{b}$ & 80 & 340 & 50 & 460 & 70 & 180 & 20 \\
\hline $\begin{array}{l}\text { Average amino } \\
\text { acid value }\end{array}$ & 400 & & 580 & & 430 & & 580 & & 200 & \\
\hline $\mathbf{N}$ & $1280^{a}$ & 270 & $1600^{b}$ & 130 & 1510 & 210 & 1790 & 230 & 710 & 80 \\
\hline
\end{tabular}

$a, b$, Within rows, means followed by different superscripts differed significantly $(P<0.05)$.

- For details, see Table 2.

Table 6. Amino acid appecrance $(+)$ or disappearance $(-)$ in the large intestine of pigs determined as the difference between faecal and ileal values of endogenous output at different levels of dietary fibre ( $\mathrm{mg} / \mathrm{kg}$ dry matter intake)

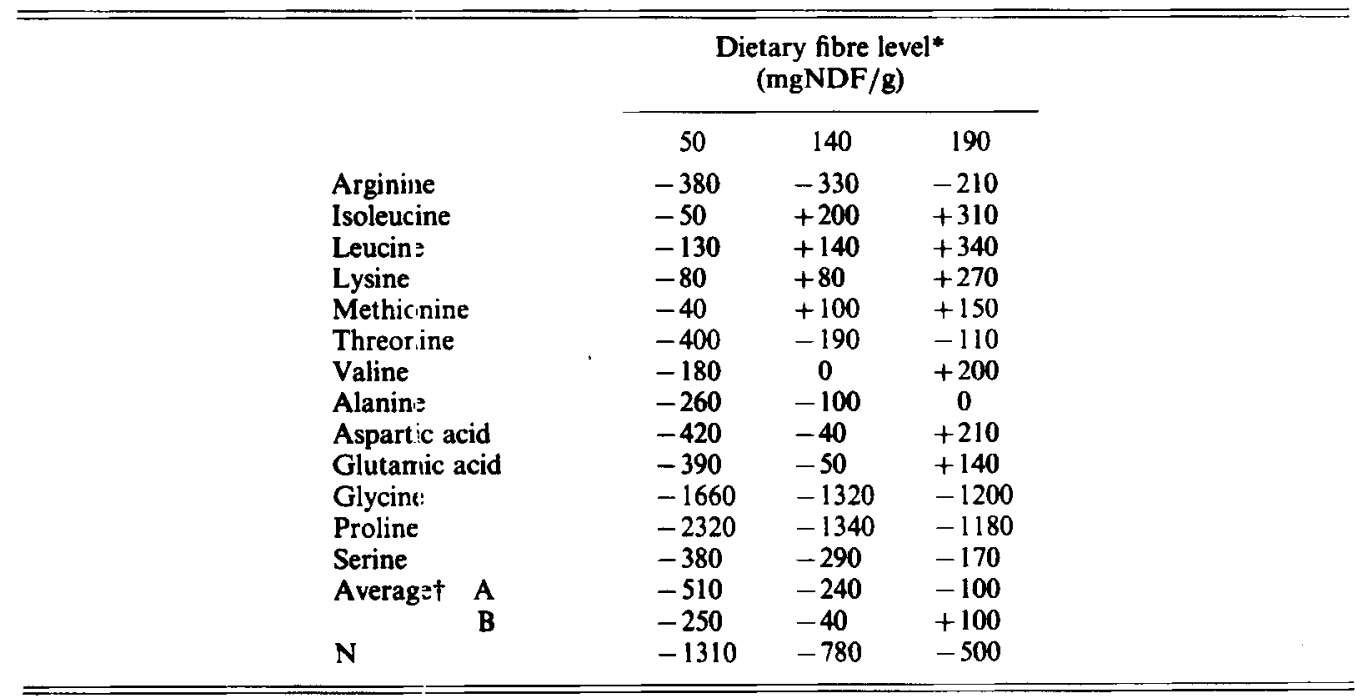

- Approximate fibre levels of the PF5 diet and of the wheat and barley diets respectively.

† Average A includes all amino acids listed whereas B excludes glycine and proline. 
several regression coefficients were not significant while others were significant but negative. In nearly all instances the intercept in the regression equations which provided the estimates of endogenous amino acid flow was significantly greater than zero. The variation between pigs in these estimates of endogenous ileal amino acids was particularly large for proline and glycine. For example, in the wheat series the endogenous proline and glycine levels for pig A were respectively 10.0 and 2.4 times greater than those for pig D. Because of the relatively large contribution of these two amino acids to total output for pig A, the total endogenous $\mathbf{N}$ output of pig $\mathrm{A}$ was more than twice that of pig $\mathrm{D}$. There was much less variation between pigs for the other endogenous amino acid values.

A comparison between the wheat and barley series was made for endogenous amino acids and $\mathrm{N}$ values determined with the two pigs given diets in both series (pigs $\mathrm{A}$ and $\mathrm{E}$ ). These values are presented in Table 4. Except for leucine for which there was more $(P<0.05)$ with the barley diets, and valine for which there was less $(P<0.05)$ with the barley diets, there were no significant differences in endogenous ileal amino acid values determined by extrapolation from diets containing graded levels of wheat or barley in which there was approximately 140 or $190 \mathrm{mg} \mathrm{NDF} / \mathrm{g}$ respectively.

The values of endogenous ileal amino acids and $\mathrm{N}$ for all seven determinations were combined in mean values weighted by the inverse of the variances. The weighted means are presented in Table 4 . These values are generally similar to those presented for pigs A and $\mathbf{E}$ but because more weight was attached to the relatively low levels of proline and glycine of pigs $C$ and $D$ due to their relatively low error values, the mean values of glycine, total $\mathbf{N}$ and particularly proline are lower. The average endogenous values of all other amino acids in Table 4 were 500 and $480 \mathrm{mg} / \mathrm{kg}$ DM intake for pigs $A$ and $E$ for wheat and barley diets respectively, and $490 \mathrm{mg} / \mathrm{kg}$ DM intake for the over-all weighted mean.

Values from protein-free diets. The average outputs of endogenous amino acids from those collections that were completed successfully are presented in Table 4 . For $\mathbf{N}$ and all other amino acids studied except threonine and proline, endogenous levels were greater $(P<0.05)$ with pigs given a diet with $50 \mathrm{~g}$ Solkafloc/ $\mathrm{kg}$ than with no added fibre.

\section{Endogenous faecal output}

Extrapolated values. For $\mathrm{N}$ and the majority of the amino acids determined, endogenous faecal outputs from pigs given barley were greater $(P<0.05)$ than that from pigs given wheat and there was a similar trend for all other amino acids. The comparison between values determined with the different grains was made with pigs $A$ and $E$; these average values and the over-all values for endogenous $\mathbf{N}$ and amino acid output for each diet are presented in Table 5.

Many of the regression coefficients were not significant for the relationships determined with individual pigs, but for most amino acids the intercept was significantly greater than zero. When determined using the combined values for all pigs given each diet series, generally faecal output was significantly related to dietary intake. The values of the intercept from these regressions, which were similar to the weighted mean values from the individual regressions, were used as the estimates of endogenous faecal output in Table 5.

Values from protein-free diets. The average values of faecal $\mathrm{N}$ and amino acid output from the pigs given a protein-free diet with $50 \mathrm{~g}$ added cellulose $/ \mathrm{kg}$ are also contained in Table 5 . No faeces were produced during the $3 \mathrm{~d}$ collection period from pigs given the diet containing no fibre. 


\section{DISCUSSION}

The composition of endogenous ileal digesta determined both by extrapolation and with protein-free diets conforras with previous estimates made with pigs given protein-free diets by Holmes et al. (1974) and Sauer et al. (1977). The four most abundant amino acids in endogenous ileal digesta in each of these estimates were proline, glycine, glutamic acid and aspartic acid in order of decreasing abundance, with serine and threonine being next most abundant in the present experiment. These six amino acids are also those reported by Pigman (1963) and Horowitz (1967) to occur most abundantly in mucin protein. Mucins are secreted in large amounts by the epithelium of the gastrointestinal tract but they have been found by Hashimoto et al. (1963) to be largely resistant to proteolytic enzymes. Thus, it appears likely that mucin protein is a major source of endogenous nitrogen in the ileum. There are certain other characteristics of the absorption of these amino acids that may also be significant factors in their predominant occurrence in endogenous digesta. Protein digestion in the small intestine occurs by the sequential action of specific endopeptidases and exopeptidases which, through their specific sites of action (see review by Gray \& Cooper, 1971) provide the intestinal cells with a mixture of free, basic and neutral amino acids and small peptides. There is a large volume of literature on the digestion and absorption of peptides (see review by S.lk, 1980) and generally it appears that different peptidases are located for digestion both in the brush border and within the intracellular fluid of the intestinal cells. Brush border peptidases have specificity appropriate for small peptides composed of neutral amino acids, but they lack hydrolytic activity for dipeptides that contain proline (Wojnarowska \& Gray, 1975). Peptidases that hydrolyse dipeptides containing proline, glycins: and some other amino acids have been found by Rubino et al. (1971) and Dolly \& Fottrell (1969) to be located within the intestinal epithelial cells. Thus Gray \& Cooper (1971) have suggested that following the digestion of dietary proteins only the neutral amino acids and the two basic amino acids, arginine and lysine, are quantitatively absorbed from the intestine as amino acids. The imino acids (proline and hydroxyproline), glycine, the hydroxy-substituted amino acids (serine and threonine) and the dicarboxylic acids (glutamic and aspartic acids) all appear to enter as constituents of small peptides where specific intracellular pepticlases hydrolyse them. However, a feature of the absorption of proline and glycine as peptides is the considerable reflux of the free amino acids back into the lumen. Heading $e t$ al. (1977) for example, found that over $30 \%$ of glycine and $10 \%$ of proline absorbed as peptide had returned to the lumen as the free amino acid. Similarly, Gardner (1975) measured the rates of absorption of amino acids (corrected for endogenous losses) from the rat intestine perfused with a pancreatic digest of casein containing a mixture of free amino acids and peptides. He found rates of absorption of proline, glycine, glutamic and aspartic acids to be $-5.3,-1.9,-0.5$ and $0.2 \mu \mathrm{M} / \mathrm{m}$ per $\mathrm{h}$, respectively, compared to a mean for all other amino acids of $10.5 \mu \mathrm{M} / \mathrm{m}$ per $\mathrm{h}$. Gardner's (1975) results suggested that although peptide-bound proline was well absorbed, free proline liberated by hydrolysis appeared to pass back into the gut lumen as well as into the tissue fluid. Gardner (1976) found in further experiments that amino acid absorption was not inhibited by peptides, which according to Mathews (1972) and others, are absorbed by different mechanisms. Therefore, once the amino acids reappear in the lumen, they should subsequently be absorbed (Heading et al. 1977).

It is probably no coincidence that the four most abundant amino acids in endogenous ileal digesta are also those usually absorbed in peptides and that may subsequently reappear, in part, in the lumen for riabsorption as the free amino acid. Therefore, the consistent pattern of abundance of amino acids in endogenous ileal digesta is probably due both to the secretion of mucus containing these amino acids and to their slow absorption from the 
intestine, both because of their characteristic methods of absorption and their occurrence in poorly digested proteins.

Although proline and glycine are amino acids of only minor nutritional importance, their large and variable output was a feature of these results and also those of Sauer et al. (1977). Sauer $e t$ al. (1977) found true digestibility coefficients exceeding 1.00 for these amino acids and concluded that values of proline and glycine determined with protein-free diets over-estimated endogenous values. Furthermore, they suggested that endogenous estimates of all other amino acids are probably also over-estimated. However, the present results of the extrapolation method suggest that proline and glycine might be exceptional; for these amino acids alone ileal levels were negatively related to dietary intake for some animals. Thus, the superabundant proportions of proline and glycine found in endogenous ileal digesta of pigs appears from the present results to be an artefact of the low-protein or protein-free diets often used to determine endogenous output. Consequently, true digestibility estimates for these amino acids in excess of 1.00 should not necessarily invalidate estimates of endogenous output of other amino acids as suggested by Sauer et al. (1977).

Another feature of the present results was the similarity between estimates of endogenous ileal amino acid values determined by extrapolation from two series of diets containing approximately 140 or $190 \mathrm{mg} \mathrm{NDF} / \mathrm{g}$. At lower levels of fibre, endogenous ileal values determined with animals given diets free of protein were significantly influenced by dietary fibre content.

The latter result is consistent with those reported by Sauer et al. (1977) who also found that values of endogenous ileal amino acid output were markedly increased as dietary fibre was increased with the additions of cellulose (alphafloc) at 50 or $100 \mathrm{mg} / \mathrm{g}$, as the fibre source. With a diet containing $150 \mathrm{mg}$ cellulose/g, Sauer et al. (1977) suggested there might be a smaller increase in endogenous output, but difficulties with the ileal cannulas limited the results for this treatment. Nevertheless, excluding glycine and proline, average endogenous amino acid levels from both experiments were related $(r 0.98, P<0.05)$ to the level of dietary fibre (Fig. 1). Endogenous levels determined by extrapolation appeared not to fit this relationship. Either the extrapolation method provides lower values at a similar fibre level than the protein-free diets, or the values from both methods may be considered comparable and over-all the response of endogenous ileal amino acid levels to increasing dietary fibre is considerably diminished at dietary NDF concentrations in excess of approximately $100 \mathrm{mg} / \mathrm{g}$.

Sauer (1976) suggested that the increase in endogenous output caused by increased fibre intake was due to increased cellular losses of epithelial cells or increased mucus secretion or both. He suggested also that by increasing dietary fibre levels by the addition of cellulose the water holding capacity of the digesta decreased, causing an increase in physical abrasion of epithelial cells by the digesta. In the present experiment, however, increased levels of cellulose in the wheat and barley series of diets had no effect on the dry matter content of the digesta (Table 3). Furthermore, an increase in the average amount of indigestible dry matter passing through the ileum from $148 \mathrm{~g} / 12 \mathrm{~h}$ with the wheat diets to $182 \mathrm{~g} / 12 \mathrm{~h}$ with the barley diets caused no apparent increase in endogenous protein, and therefore no increase in epithelial cell loss or mucus secretion. Furthermore, Rolls et al. (1978) found that the inclusion of bran in the diet of chickens previously fed a low-residue diet had no effect on cell turnover in the intestinal epithelium.

Therefore, with the similarity in amino acid composition of mucin protein and endogenous digesta of pigs fed with different levels of fibre, the results suggest that increased dietary fibre was probably directly associated with increased mucin secretion up to an apparent maximum at levels of approximately $100 \mathrm{mg} \mathrm{NDF} / \mathrm{g}$. Thus, in determining endogenous ileal values appropriate to the levels expected to occur with pigs given cereal diets, the average of the values determined by extrapolation from wheat and barley diets appears well suited 


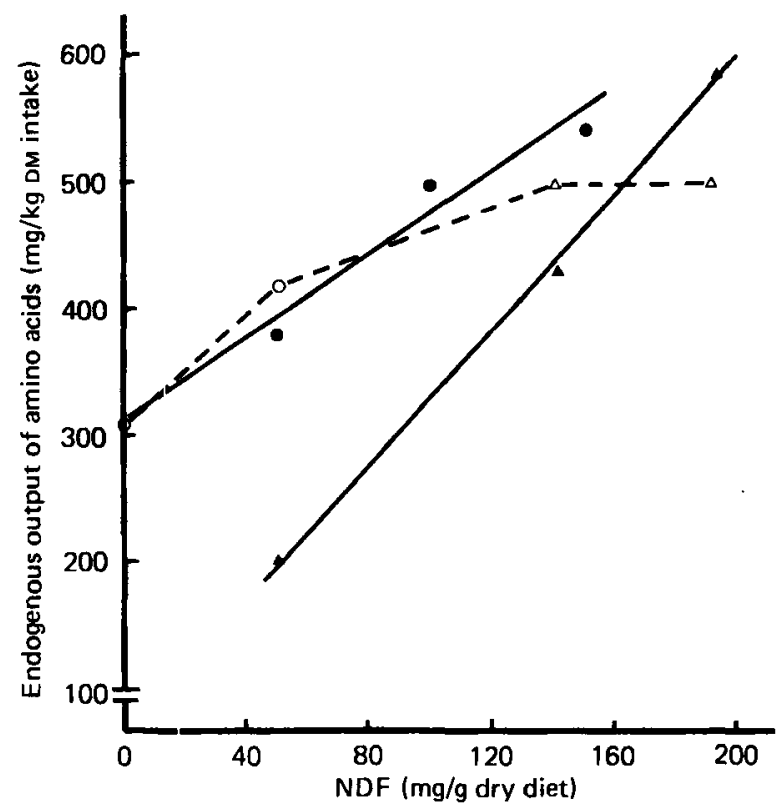

Fig. 1. Relationships of the average output of endogenous amino acids ( $\mathrm{mg} / \mathrm{kg}$ dry matter (DM) intake) $(X)$ v. dietary neutral detergent fibre (NDF) $(\eta$ level $(\mathrm{mg} / \mathrm{g})$ in pigs given a protein-free diet series (for details, see Table 2). Endogenous ileal output values determined with protein-free diets in the present experiment $(O)$ and by Sauer ot al. $(1977)(O)$, and by extrapolation $(\triangle)$ in the present study. For the protein-free values: $Y=31.88+0.016 X(r 0.98, P<0.01)$. Endogenous faecal values $(\triangle)$ from the present experiment: $Y=6 \cdot 19+0.027 X(r 0.99, P<0.01)$.

for application to most cereal diets. However, where dietary fibre levels fall below $100 \mathrm{mg} \mathrm{NDF} / \mathrm{g}$, as they might with maize and sorghum (Sorghum vulgare Pers.) and with a small proportion of wheats, endogenous ileal levels should be corrected for dietary fibre according to linear relationships similar to that in Fig. 1.

The differences between ilial and faecal values of endogenous amino acid output varied between different levels of dietary fibre (Table 6). Over all there was a net loss of amino acids during the passage of digesta through the large intestine. However, as the level of dietary fibre increased, the average net disappearance of amino acids in the large intestine decreased from 510 to $100 \mathrm{mg} / \mathrm{kg}$ DM intake. This average was weighted by the large losses of proline and glycine and average values of all other amino acids indicated a net loss in the large intestine at levels of 50 and $140 \mathrm{mg}$ fibre $/ \mathrm{g}$, but a net gain of amino acids at the highest dietary fibre level. There was considerable variation between amino acids; those that showed the largest increase over this range in dietary fibre were aspartic and glutamic acids and leucine. These amino acids are also those that Mason $e t$ al. (1976) found most abundant in bacterial protein from pig faeces. Mason et al. (1976) found a large proportion of faecal $\mathrm{N}$ from pigs to be of bacterial origin. This is supported in the present work by the general similarity in the amino acid patterns of endogenous faecal protein and bacterial protein, and the dissimilarity between endogenous faecal and ileal proteins. The evidence suggests therefore, that the hind-gut micro-flora is able to assimilate endogenous proteins and that the rate of fermentation, and hence bacterial protein in faeces, was stimulated by additional substrate provided by increased fibre intake. Clearly, both the level of fermentation and availability of exogenous and endogenous proteins to bacterial attack will determine the proportion of endogenous ileal amino acids appearing in the faeces (Mason \& Palmer, 1973).

This concept challenges the basic assumptions made about endogenous faecal $\mathrm{N}$ output 
(Mitchell, 1924), as it appears that the amount of endogenous $\mathrm{N}$ excreted in the faeces need not be directly related to either DM intake or indigestible DM or to the total amount of $\mathrm{N}$ secreted into the alimentary canal. Thus, there would appear to be little value in calculating true digestibility of amino acids by the classical method of correcting apparent faecal digestibility values by amino acid levels in the faeces of pigs given protein-free diets.

The authors wish to thank Mr A. R. Alimon for his help with the surgical preparation of pigs, Dr V. Bofinger for statistical advice and Mrs B. Ward and W. Beresford for their assistance in the laboratory. Dr M. R. Taverner was in receipt of a postgraduate scholarship from the Australian Pig Industry Research Committee.

\section{REFERENCES}

Angus, R., Sutherland, T. M. \& Farrell, D. J. (1977). Proc. Nutr. Soc. Aust. $2,90$.

Ash, R. W. (1962). Anim. Prod. 4, 309.

Borgida, L. P. \& Laplace, J. P. (1977). Annls Zootech. 26, 395.

Clare, N. T. \& Stevenson, A. E. (1964). N.Z. Jl agric. Res. 7, 198.

Dolly, J. O. \& Fottrell, P. F. (1969). Clin. Chim. Acta. 26, 555.

Frape, D. L., Wolf, K. L., Wilkinson, J. \& Chubb, L. C. (1968). J. Inst. Anim. Technicians 19, 61.

Gardner, M. L. G. (1975). J. Physiol. 253, 233.

Gardner, M. L. G. (1976). J. Physiol. 255, 563.

Gray, G. M. \& Cooper, H. L. (1971). Gastroenterology 61, 535.

Hashimoto, Y., Tsuiki, S., Nisizawa, K. \& Pigman, W. (1963). Ann. N.Y. Acad. Sci. 106, 233.

Heading, R. C., Schedl, H. P., Stegink, L. D. \& Miller, D. L. (1977). Clin. Sci. mol. med. 52, 607.

Holmes, J. H. G., Bayley, H. S., Leadbeater, P. A. \& Horney, F. D. (1974), Br, J. Nutr. $32,479$.

Horowitz, M. I. (1967). Handbook of Physiology: Section 6, Alimentary Canal [C. F. Code, editor]. Washington, DC: American Physiological Society.

Ivan, M. (1974). A nutritional evaluation of wheat for pigs with a particular reference to quality and quantity of protein. PhD Thesis, University of New England.

Laplace, J. P. \& Borgida, L. P. (1976). Annls Zootech. 25, 361.

Low, A. G. (1976). Proc. Nutr. Soc. 35, 57.

Mason, V. C., Just, A. \& Bech-Anderson, S. (1976). Z. Tierphysiol. Tiernernähr. Futtermittelk 36, 310.

Mason, V. C. \& Palmer, R. (1973). Acta Agric. Scand. 23, 141.

Mathews, D. M. (1972). Proc. Nutr. Soc. 31, 171.

Miller, E. L. (1976). In Reviews in Rural Science, Vol. 2, p. 47 [T. M. Sutherland, J. R. McWilliam and R. A. Leng, editors]. Armidale: University of New England Publishing Unit.

Mitchell, H. H. (1924). J. biol. Chem. 58, 873.

Pigman, W. (1963). Ann. N.Y. Acad. Sci. 106, 808.

Rolls, B. A., Turvey, A. \& Coates, M. E. (1978). Br. J. Nutr. 39, 91.

Rubino, A., Field, M. \& Schwachman, H. (1971). J. biol. Chem. 246, 3542.

Sauer, W. C. (1976). Factors affecting amino acid availability for cereal grains and their components for growing monogastric animals PhD Thesis, University of Manitoba.

Sauer, W. C., Stothers, S. C. \& Parker, R. J. (1977). Can. J. Anim. Sci. 57, 775.

Silk, D. B. A. (1980). Proc. Nutr. Soc. 39, 61.

Spackman, D. H., Stein, W. H. \& Moore, S. (1958). Analyt. Chem. 30, 1190.

Sukhatmé, P. V. (1938). Sankhyá. 4, 39.

Van Soest, P. J. \& Wine, R. H. (1967). J. Ass. off. agric. Chem. 50, 50.

Wojnarowska, F. \& Gray, G. M. (1975). Biochim. biophys. Acta. 403, 147.

Zebrowska, T., Buraczewska, L., Pastuszewska, B., Chamberlain, A. G. \& Buraczewski, S. (1978). Roczn. Nauk roln. Ser. B 99, 75. 